\title{
Common Variable Immunodeficiency
}

National Cancer Institute

\section{Source}

National Cancer Institute. Common Variable Immunodeficiency. NCI Thesaurus. Code C26725.

A primary immunodeficiency characterized by low levels or absence of all the immunog lobulin classes and lack of B-lymphocytes or plasma cells. It results in recurrent bacterial infections. Complications include autoimmune phenomena and cancer development. 